\title{
Panjang Dan Volume Akar Tanaman Padi Lokal Sulawesi Utara Saat Kekeringan Yang Diinduksi Dengan Polietilen Glikol 8000
}

\author{
Crestie Mangansigea, Nio Song $\mathrm{Ai}^{*}$, Parluhutan Siahaana* \\ aJurusan Biologi, FMIPA, Unsrat, Manado
}

KATA K UNCI

Kekeringan

PEG 8000

Panjang akar

Volume akar

Padi lokal Sulut

\begin{abstract}
A B S T R A K
Kekeringan berdampak buruk terhadap produktivitas dan produksi pangan di dunia. Penelitian ini bertujuan untuk mengkaji ada tidaknya perbedaan respons morfologis berdasarkan panjang dan volume akar pada tanaman padi lokal Sulawesi Utara (varietas Superwin, Ombong, Temo, dan Burungan) yang mengalami kekeringan dengan induksi PEG 8000. Tanaman padi dengan empat daun yang telah berkembang penuh pada fase vegetatif diberi perlakuan kekeringan yang diinduksi dengan PEG 8000 (potensial air/PA medium 0; -0,25; -0,5 MPa) selama 6 jam. Hasil penelitian menunjukkan bahwa faktor varietas, faktor konsentrasi PEG 8000, faktor waktu perlakuan, interaksi antara faktor varietas dan konsentrasi PEG, interaksi antar faktor varietas dan waktu perlakuan, interaksi antara faktor konsentrasi dan waktu perlakuan, interaksi antara faktor varietas, konsentrasi PEG dan waktu perlakuan tidak menyebabkan perbedaan panjang dan volume akar. Dalam penelitian ini panjang dan volume akar tidak dapat dijadikan sebagai indikator cekaman kekeringan pada keempat varietas padi lokal Sulawesi Utara.
\end{abstract}

KE Y W O R D S

Drought

PEG 8000

Root length

Root volume

North Sulawesi local rice
A B S T R A C T

Drought decreases the productivity and production of food in the world. This study aimed to evaluate the differences of morphological responses based on root length and volume in North Sulawesi local rice (cv. Superwin, Ombong, Temo, dan Burungan) under PEG-8000-induced drought. The 4-fully-expanded-leaf plants at the vegetative phase were treated by growing the plants in the PEG 8000 solution with water potential/PA 0; -0.25; -0.5 MPa or 6 hours. The results showed that factors of variety, PEG 8000 concentration, treatment period, interaction between variety and PEG 8000 concentration, interaction between variety and treatment period, interaction between PEG 8000 concentration and treatment period, interaction among variety, PEG 8000 concentration and treatment period did not result in any differences in root length and volume. Root length and volume were not able to be used as drought indicators of in these four North Sulawesi local rice
TERSEDIA ONLINE

01 Agustus 2018

\section{Pendahuluan}

Kekeringan merupakan keadaan kekurangan pasokan air pada suatu daerah dalam waktu yang lama yang disebabkan oleh rendahnya curah hujan secara terus-menerus, atau periode panjang tanpa hujan, seperti musim kemarau panjang. Kondisi ini dapat mengakibatkan habisnya cadangan air tanah akibat penguapan (evaporasi), transpirasi, atau penggunaan lain oleh manusia secara terusmenerus (WMO, 1974). Indonesia memiliki lahan kering sekitar 148 juta ha (78\%) dan lahan basah (wet lands) seluas 40,20 juta ha $(22 \%)$ dari total 188,20 juta ha luas daratan pada tahun 2012 (Badan Kordinasi Penataan Ruang Nasional, 2012). Lahan persawahan yang mengalami kekeringan selama Januari - Juli 2011 sekitar 84.365 ha dan

\footnotetext{
${ }^{*}$ Corresponding author: Jurusan Biologi FMIPA UNSRAT, Jl. Kampus Unsrat, Manado, Indonesia 95115

Email address: niosongai@unsrat.ac.id

Published by FMIPA UNSRAT (2018)
} 
hanya sekitar 8.373 ha pada periode yang sama pada tahun 2010 (Wahyudi, 2012). Kekeringan berdampak buruk terhadap produktivitas dan produksi pangan di dunia (Wood, 2005). Oleh karena itu perlu dilakukan langkah-langkah antisipatif dan strategis untuk mengatasi masalah kekeringan ini, antara lain dengan penanaman varietas padi tahan kering sebagai sumber bahan pangan untuk mengembangkan bidang pertanian di masa mendatang (Ashraf dan Fooland, 2007).

Perlakuan kekeringan yang disebabkan oleh kurangnya ketersediaan air di lingkungan sekitar tanaman secara in vitro dapat diinduksi dengan menambahkan polyethylene glycol (PEG) pada media tumbuh (Widoretno et al., 2003). PEG merupakan senyawa yang stabil, non ionik, polimer panjang yang larut dalam air, dan dapat menurunkan potensial air (PA) media tumbuh tanpa menyebabkan keracunan. Dengan demikian kerusakan atau kematian tanaman pada perlakuan kekeringan yang diinduksi dengan PEG merupakan efek kekeringan, bukan merupakan efek langsung dari senyawa PEG karena senyawa tersebut tidak diserap oleh tanaman (Dami, 1997).

Panjang akar merupakan salah satu karakter morfologi yang dilaporkan terkait dengan ketahanan tanaman terhadap kekeringan (Bohn et al., 2006; Torey, 2013). Tanaman dengan volume akar yang tinggi dapat mengabsorbsi lebih banyak air sehingga mampu bertahan pada kondisi kekurangan air (Palupi dan Dedywiryanto, 2008). Peningkatan volume akar merupakan respons morfologis yang penting dalam proses adaptasi tanaman terhadap kekurangan air (Budiasih, 2009). Penelitian ini bertujuan untuk mengkaji ada tidaknya perbedaan respons morfologis berdasarkan panjang dan volume akar pada tanaman padi lokal Sulawesi Utara yang mengalami kekeringan dengan induksi PEG 8000 dengan menumbuhkan tanaman padi pada medium dengan PA 0; -0,25; -0,5 MPa pada fase vegetatif.

\section{Material dan Metode}

Penelitian ini dilaksanakan dirumah kaca di Kelurahan Tingkulu, Manado, Sulawesi Utara selama delapan minggu dan dilanjutkan dengan di Laboratorium Ekologi Jurusan Biologi FMIPA Universitas Sam Ratulangi selama tiga minggu. Bahan yang digunakan dalam penelitian ini adalah padi varietas Superwin, Ombong, Temo, dan Burungan, tanah, garam, telur ayam, larutan pemutih komersial Bayclin ${ }^{\circledR}$, pupuk Gandasil $D^{\circledR}$, air, polietilen glikol (PEG) 8000, larutan hidroponik. Penelitian yang dilakukan merupakan percobaan faktorial dalam Rancangan Acak Kelompok (RAK) dengan tiga macam perlakuan kekeringan yang diinduksi dengan PEG 8000 dengan potensial air (PA) medium 0, -0,25 dan -0,5 MPa dalam tiga kali ulangan.
Dalam penelitian ini tahapan kerja dimulai dari seleksi benih, perkecambahan benih, pemeliharaan tanaman, perlakuan kekeringan, pengukuran parameter dan analisis data. Untuk mengetahui kualitasnya, benih padi direndam selama 2 jam dalam air garam. Benih yang baik adalah benih yang tenggelam di dasar air. Benih tersebut diambil dan disterilisasi dengan menggunakan pemutih komersial 2\% selama 2 menit dan diulang 3 kali, kemudian dibilas dengan air bersih. Kemudian benih dikecambahkan dalam wadah berisi media tanam yang diisi tanah dan pupuk NPK ( 6 g pupuk NPK dalam $7 \mathrm{~kg}$ tanah), kemudian media disiram dengan air sampai kapasitas lapang. Padi disiram dengan campuran air dan campuran pupuk Gandasil D (10 g pupuk Gandasil D dalam $10 \mathrm{~L}$ air) sampai mencapai tahap 4 daun yang berkembang penuh atau 4 fully expanded leaf dalam waktu 4 minggu (modifikasi Nio dan Ludong, 2013).

Sebelum perlakuan kekeringan dimulai, tanaman padi dibersihkan dan dipindahkan ke dalam gelas plastik berukuran $240 \mathrm{~mL}$ yang telah berisi $100 \mathrm{~mL}$ larutan hidroponik. Tanaman padi tersebut diadaptasikan selama 1 minggu dengan menggunakan shaker berkecepatan 50 opm di dalam ruangan yang bersuhu $25^{\circ} \mathrm{C}$ dengan bantuan sinar cahaya lampu (cool white 36 Watt, 2880 lumen) selama 12 jam per hari. Perlakuan kekeringan diberikan dengan menambahkan PEG 8000 ke dalam larutan hidroponik. Larutan PEG dengan PA 0, -0,25 dan -0,5 MPa dibuat dengan menambahkan masing-masing $0 \mathrm{~g}, 135 \mathrm{~g}$ dan $198 \mathrm{~g}$ PEG 8000 ke dalam 1000 mL larutan hidroponik (modifikasi Nio et al., 2011). Kultur tanaman padi dilakukan dalam gelas plastik berukuran $240 \mathrm{~mL}$, kemudian diisi dengan satu macam medium dan ditutup dengan spons pada bagian mulut gelas sebagai penyangga tanaman padi (modifikasi Nio dan Kandou, 2000). Pengambilan data dilakukan sebanyak 2 kali, yaitu jam ke-0 dan 6 (modifikasi Nio et al., 2011).

Panjang akar diukur mulai dari bagian pangkal akar sampai pada ujung akar dengan penggaris (Rusd, 2009). Volume akar ditentukan dengan cara menentukan volume awal air yang akan dimasukkan ke dalam gelas ukur, memasukkan akar ke dalam gelas ukur dan kemudian mencatat pertambahan volume air setelah memasukkan akar ke dalamnya (Munarso, 2011). Data yang diperoleh dianalisis dengan analisis varian dan dilanjutkan dengan uji Duncan 5\% untuk data yang berbeda nyata.

\footnotetext{
3. Hasil dan Pembahasan

\section{Panjang Akar}

Panjang akar merupakan salah satu kriteria yang dapat digunakan untuk mengetahui luas daerah jangkauan akar dalam mencari sumber daya air dan karakter ini dipengaruhi oleh perbedaan sistem pengairan (Munarso, 2011). Panjang akar merupakan salah satu karakter morfologi yang dilaporkan terkait dengan ketahanan tanaman terhadap kekeringan (Bohn et al., 2006; Torey et al.,
} 
2013). Panjang akar menggambarkan kemampuan tanaman untuk memperoleh suplai air termasuk unsur-unsur hara di lapisan tanah yang lebih dalam (Munarso, 2011). Beberapa penelitian yang mengukur panjang akar sebagai respons morfologis tanaman terhadap cekaman kekeringan, antara lain dilakukan oleh Torey et al. (2013), Palit (2015) dan Kakanga (2017).

Tabel 1. Panjang dan volume akar padi varietas Superwin, Ombong, Temo, dan Burungan dengan perlakuan PEG 8000 selama 6 jam (rata-rata \pm SE)

$\begin{array}{ccccc}\text { Varietas } & \begin{array}{c}\text { PEG } \\ \text { (MPa) }\end{array} & \begin{array}{c}\text { Jam } \\ \text { Ke- }\end{array} & \begin{array}{c}\text { Panjang } \\ \text { Akar }(\mathrm{cm})\end{array} & \begin{array}{c}\text { Volume } \\ \text { Akar }(\mathrm{mL})\end{array} \\ \text { Superwin } & 0 & 0 & 14,63 \pm 0,07 & 20,32 \pm 0,02 \\ & & 6 & 13,83 \pm 2,33 & 20,86 \pm 0,57 \\ & -0,25 & 0 & 14,63 \pm 0,07 & 20,32 \pm 0,02 \\ & & 6 & 14,9 \pm 3,43 & 20,26 \pm 0,06 \\ \text { Ombong } & -0,5 & 0 & 14,63 \pm 0,07 & 20,32 \pm 0,02 \\ & & 6 & 10 \pm 1,66 & 20,23 \pm 0,06 \\ & & 0 & 12,97 \pm 1,02 & 20,25 \pm 0,05 \\ & -0,25 & 0 & 12,4 \pm 1,7 & 20,26 \pm 0,12 \\ & & 6 & 14,86 \pm 1,02 & 20,25 \pm 0,05 \\ \text { Temo } & -0,5 & 0 & 12,97 \pm 1,02 & 20,33 \pm 0,33 \\ & & 6 & 12,4 \pm 4,30 & 20,25 \pm 0,05 \\ & 0 & 0 & 12,06 \pm 0,56 & 20,31 \pm 0,03 \\ & & 6 & 12,26 \pm 1,71 & 20,3 \pm 0,05 \\ & -0,25 & 0 & 12,06 \pm 0,56 & 20,31 \pm 0,05 \\ & & 6 & 13,76 \pm 2,7 & 20,4 \pm 0,05 \\ \text { Burungan } & -0,5 & 0 & 12,06 \pm 0,56 & 20,31 \pm 0,05 \\ & & 6 & 11,93 \pm 0,54 & 20,43 \pm 0,06 \\ & 0 & 0 & 14,53 \pm 2,93 & 20,24 \pm 0,08 \\ & & 6 & 17,03 \pm 5,06 & 21,13 \pm 0,98 \\ & -0,25 & 0 & 14,53 \pm 2,93 & 20,24 \pm 0,08 \\ & & 6 & 15,36 \pm 2,36 & 20,16 \pm 0,06 \\ & -0,5 & 0 & 14,53 \pm 2,93 & 20,24 \pm 0,08 \\ & & 6 & 14,5 \pm 1,73 & 20,36 \pm 0,13\end{array}$

Hasil analisis varian menunjukkan bahwa faktor varietas, faktor konsentrasi PEG 8000 , faktor waktu perlakuan, interaksi antara faktor varietas dan konsentrasi PEG, interaksi antar faktor varietas dan waktu perlakuan, interaksi antara faktor konsentrasi PEG dan waktu perlakuan, interaksi antara faktor varietas, konsentrasi PEG dan waktu perlakuan tidak menyebabkan perbedaan panjang akar (Tabel 1), sehingga tidak dilanjutkan dengan uji Duncan 5\%. Hal ini menunjukkan bahwa kekeringan yang diinduksi dengan PEG 8000 tidak berpengaruh panjang akar.

Hasil penelitian Torey et al. (2013) menunjukkan bahwa panjang akar padi Superwin dan IR 64 pada perlakuan yang tidak diairi selama 14 hari adalah $67 \%$ lebih besar daripada yang diairi. Palit (2015) melaporkan panjang akar padi varietas Superwin lebih pendek dari pada varietas Ombong, Temo, dan Burungan baik yang diairi maupun tidak diairi. Kakanga (2017) melaporkan bahwa panjang akar tanaman keempat varietas padi yang mengalami perlakuan kekeringan $(21,6 \mathrm{~cm})$ adalah $5,5 \%$ lebih kecil dibandingkan dengan kontrol (25,5 $\mathrm{cm})$. Penelitian ini menunjukkan bahwa panjang akar tidak bisa dijadikan indikator adanya cekaman kekeringan pada empat varietas padi lokal Sulut, karena cekaman kekeringan diinduksi dengan PEG
8000 yang berbeda dengan penelitian Torey et al. (2013), Palit (2015), dan Kakanga (2017) yang memberikan cekaman kekeringan dengan cara tidak diairi.

\section{Volume Akar}

Kemampuan akar mengabsorbsi air dengan cara memaksimalkan sistem perakaran merupakan salah satu pendekatan utama yang digunakan untuk menentukan kemampuan tanaman beradaptasi terhadap kekeringan (Efendi, 2009). Tanaman dengan volume akar yang tinggi dapat mengabsorbsi lebih banyak air sehingga mampu bertahan pada kondisi kekurangan air (Palupi dan Dedywiryanto, 2008). Kriteria ketahanan beberapa varietas padi terhadap kekeringan dapat dilihat dari sifat perakaran yang dimiliki (Sudarmawan, 2010; Nio et al., 2010; Kadir, 2011; Sadimantara dan Muhidin, 2012), di antaranya volume akar (Torey et al., 2013; Kakanga, 2017). Peningkatan volume akar merupakan respons morfologis yang penting dalam proses adaptasi tanaman terhadap kekurangan air (Budiasih, 2009).

Hasil analisis varian menunjukkan faktor varietas, faktor konsentrasi PEG 8000, faktor waktu perlakuan, interaksi antara faktor varietas dan konsentrasi PEG, interaksi antar faktor varietas dan waktu perlakuan, interaksi antara faktor konsentrasi dan waktu perlakuan, interaksi antara faktor varietas, konsentrasi PEG dan waktu perlakuan tidak menyebabkan perbedaan volume akar yang nyata, sehingga tidak dilanjutkan dengan uji Duncan $5 \%$.

Torey et al. (2013) melaporkan volume akar padi varietas Superwin dengan perlakuan tidak diairi pada hari ke-14 $(0,18 \mathrm{~mL})$ lebih kecil daripada kontrol (0,28 mL). Kakanga (2015) juga melaporkan bahwa volume akar tanaman padi varietas Superwin (2,75 mL), Ombong (3 mL), Burungan (2,5 mL), dan Temo $(1,62)$ pada perlakuan kekeringan lebih kecil dibandingkan dengan kontrol, yaitu berturut-turut $3,5,3,12,5,37$ dan 2,37 $\mathrm{mL}$ pada varietas Superwin, Ombong, Burungan dan Temo. Dalam penelitian ini volume akar tidak dapat dijadikan indikator morfologis adanya cekaman kekeringan pada keempat varietas padi lokal Sulut.

\section{Kesimpulan}

Perlakuan kekeringan yang diinduksi dengan PEG 8000 pada potensial air medium -0,25 dan $0,5 \mathrm{MPa}$ tidak menyebabkan perbedaan panjang dan volume akar, sehingga tidak dapat dijadikan sebagai indikator cekaman kekeringan pada keempat varietas padi lokal Sulawesi Utara. 


\section{Daftar Pustaka}

Ashraf, M., dan Fooland, M.R. 2007.Roles of Glycine Betaine and Proline in Improving Plant Abiotic Stress Resistance. Environ Exp Bot . 59:206216.

BKPRN, 2012.Badan Kordinasi Penataan Ruang Nasional.Menata Kawasan Hutan dan Mempertahankan Lahan Pertanian.http://www.pu.go.id/search?q=lahan \%20kritis. [15 Juni 2013].

Bohn, M., J. Novais, R. Fonseca, R. Tuberosa dan T.E Grift. 2006. Genetic Evoluation of Root Complexity in Maize. Acta Argo Hungarica. 54(3):1-13.

Budiasih. 2009. Respon Tanaman Padi Gogo terhadap Cekaman Kekeringan. Ganec Swara Edisi Khusus. 3(3):22-27.

Dami, I., and Hughes, H.G. 1997.Effect of PEGinduced Water Stress on in vitro Hardening of 'valliant' Grape. Plant Cell Tiss Org Cult. 47:97101.

Efendi, R. 2009. Metode dan Karakter Seleksi Toleransi Genotipe Jagung terhadap Cekaman Kekeringan [Tesis]. FMIPA, Bogor.

Kadir, A. 2011.Respons Genotipe Padi Mutan Hasil Iradiasi Sinar Gamma terhadap Cekaman Kekeringan. Jurnal Agrivigor. 10(3):235-246.

Kakanga, C.R.J. 2017. Respon Morfologi Tanaman Padi Lokal Sulawesi Utara terhadap Cekaman Banjir dan Kekeringan pada Fase Vegetatif. [Skripsi]. FMIPA. Universitas Sam Ratulangi. Manado.

Munarso, Y.P. 2011 .Keragaan Padi Hibrida pada Sistem Pengairan Intermittent dan Tergenang. Penelitian Pertanian Tanaman Pangan. 30(3):189-195.

Nio, S.A., Tondais, S.M., dan Butarbutar, R. 2010. Evaluasi Indikator Toleransi Cekaman Kekeringan pada Fase Perkecambahan Padi (Oryza sativa L.). Jurnal Biologi XIV:50-54

Nio, S.A., dan Banyo, Y. 2011.Konsentrasi Klorofil Daun sebagai Indikator Kekurangan Air pada Tanaman. Jurnal IImiah Sains.11(2):166-173.
Nio, S.A., dan Ludong, D.P.M. 2013. Comparing the Drought Tolerance of Local Rice Cultivar Superwin with Other Cultivars Cultivated in North Sulawesi Province Based on Dry Matter Partitioning. $4^{\text {th }}$ International Conference of Global Resource Conservation. Brawijaya University.

Palit, J.E. 2015. Karakter Morfologi Tajuk dan Akar pada Fase Vegetatif Padi Lokal Sulut Saat Kekeringan [Skripsi]. FMIPA. Universitas Sam Ratulangi. Manado.

Palupi, R.E. dan Dedywiryanto, Y. 2008.Kajian Karakter Ketahanan terhadap Cekaman Kekeringan pada Beberapa Genotipe Bibit Kelapa Sawit (Elaeis guineensis Jacq.).Jurnal Agron. 36(1):24-32.

Rusd, M.I.A. 2009. Pengujian Toleransi Padi (Oryza sativa L.) terhadap Salinitas Pada Fase Perkecambahan. [Skripsi]. Fakultas Pertanian IPB.

Sadimantara, G. R., dan Muhidin. 2012. Daya Hasil Beberapa Kultivar Padi Gogo Lokal Asal Sulawesi Tenggara pada Cekaman Kekeringan. Jurnal Agroteknos. 2:121-125.

Sudarmawan, A. 2010. Analisis Rerata Generasi Hasil Persilangan Dua Varietas Padi Tahan terhadap Cekaman Kekeringan. Journal Crop. Agro.3(1):72-75.

Torey, P.C., Nio, S.A., Siahaan, P., Mambu, S.M. 2013. Karakter Morfologi Akar sebagai Indikator Kekurangan Air pada Padi Lokal Superwin. Jurnal Bios Logos 3(2):57-64.

Wahyudi, B. 2012. Manajemen Sumber Daya Manusia.Bandung.

Widoretno, W. 2003. Seleksi In Vitro untuk Toleransi terhadap Cekaman Kekeringan pada Kedelai (Glycine max L.) dan Cara Karakterisasi Varian Somaklonal yang Toleran. [Disertasi]. Program Pascasarjana IPB.

Wood, A.J. 2005. Eco-Physiological Adaptations to Limited Water Environments. Dalam: Jenks MA, Hasegawa PM (ed) Plant Abiotic Stress. Blackwell Publishing Ltd, India. h 1-13. 